DOI: 10.32370/IA_2021_06_18

\title{
Research of Artistic and Creative Activity as a Means of Forming the Humanistic Culture of Students
}

\author{
Qian Kai \\ Postgraduate student of the Department of Social Pedagogy \\ Dragomanov National Pedagogical University (Kyiv, Ukraine)
}

\begin{abstract}
The article considers artistic and creative activity as an important tool of students' humanistic culture formation. It is noted that artistic and creative student activity is determined by subjects' specifics and the conditions in which they are realized. Considerable emphasis is also placed on understanding artistic and creative activities as necessary conditions that effects efficiency of the training process which promotes development of students' motivation for learning, emotional and figurative spheres of their personalities, creative potential, humanistic culture. Humanistic culture is defined as integral personal education of the student in a set of humanistic norms, values, ways of behavior adopted in society. It is substantiated that the formation of humanistic culture is a complex, step-by-step process of personality development of a future specialist. It turned out that artistic and creative activity is a social process associated with spiritual and practical activities of the youth which encourages them to transform the content of the activity and its humanistic orientation in emotional and figurative forms, provides aesthetic perception of the reality; it provides implementation of culturological function and is manifested in their ability to create culture; it is a socio-psychological phenomenon that determines the emotional and aesthetic activity of the youth.

It is established that artistic and creative activity develops a students' complex ability to create products of artistic and creative activities (ability to artistically and figuratively perceive the world, which combines objects and subjects and attitude to them; ability to create artistic reality: visual, subject-imitation that evoke empathy and compassion of the subject). Emphasis is placed on problem-based learning as one of the most effective methods to manifest intellectual and creative abilities of students, creativeness in independent activity, confidence and ability to work creatively. It is determined that effective means of forming a humanistic student culture of the youth is an imitation (modeling) technology associated with modeling of situations of future professional activity in educational process.
\end{abstract}

Keywords: artistic and creative activity, humanistic culture, student, personality.

Актуальність. Сучасні вимоги до підготовки майбутніх фахівців зумовлюють необхідність розвитку у них ціннісної сфери, гуманістичної культури, моральнодуховних якостей. 3 огляду на це, теорія і практика виховання розглядає різні точки зору дослідників щодо формування гуманістичної культури студентської молоді, зокрема, й щодо ролі художньої освіти у цьому процесі. Нині освіта в системі підготовки майбутніх фахівців має, з одного боку, забезпечити розмежування специфічних принципів, методів, які обгрунтовують ефективність художньо-професійної підготовки, а 3 іншого боку, на належному рівні сформувати основу їх творчого потенціалу, враховувати вплив художньо-творчої діяльності на формування у них гуманістичної культури. 
Мета статті - розкрити особливості художньо-творчої діяльності як засобу формування гуманістичної культури студентів.

Аналіз останніх досліджень і публікацій. Утвердження парадигми гуманістичного виховання простежується у працях М. Бахтіна, I. Беха, М. Кагана, В. Кан-Каліка, В. Караковського, Л. Масол, А. Москальової, Л. Петько, В. Рогової, В. Сухомлинського, В. Тернопільської, Г. Шевченко та ін. Водночас й досі малодослідженим залишається питання художньо-творчої діяльності як засобу формування гуманістичної культури студентів.

Виклад основного матеріалу. Гуманістичну культуру розуміємо як інтегральне особистісне утворення студента в сукупності гуманістичних норм, ијнностей, способів поведінки, прийнятих у сочуіумі. Гуманістична культура характеризується гуманістичною освіченістю, гуманістичною позицією та гуманістичною поведінкою студента.

Художньо-творча діяльність як засіб формування гуманістичної культури студентів $є$ вираженням їх активності й спрямовується певними мотивами для досягнення конкретної мети. Вона $є$ складним усвідомленим поліструктурним утворенням. Продуктом художньо-творчої діяльності виступають специфічні духовноестетичні цінності (твори мистецтва). На думку М. Когана, розуміння специфіки художньо-творчої діяльності [2] лежить в структурі людської психіки, яка здатна до художньо-образного відтворення реальності. Естетика називає цю здатність людської психіки образним мисленням, творчою фантазією, емоційним самовираженням, художньо-образним відображенням об’єктивної реальності, іiі духовно-практичним освоєнням. Всі механізми людської психіки діють спільно, нероздільно, знаходячись в синкретичній єдності, відрізняючись один від одного тільки в теоретичному аналізі. Своєю чергою, виходячи поза межі реального світу уяви, людина в процесі художньотворчої діяльності зберігає вірність реальності, оскільки така діяльність організовує свою поведінку за іiі законами. I перший із них, на думку М. Когана, - різнобічність реального життя, яке пов'язує в одну систему працю, пізнання, спілкування й ціннісні орієнтації людини [2]. У даному аспекті художньо-творча діяльність моделює цю систему, зокрема, виступає як особлива, специфічна форма практичної діяльності, особлива форма спілкування людей, особлива форма пізнання та особлива форма іï ціннісних орієнтацій. Саме ця єдність і трактується як художність. 
Художність є духовно-матеріальною сутністю, що виявляється в художній творчості індивіда, матеріалізується в продуктах його творчості. Художньо-творча діяльність об'єднує всі види людської діяльності, в ній інтегруються і поєднуються енергії пізнавальної, ціннісно-орієнтаційної, перетворювальної та діяльності спілкування. Отже, специфіка художньо-творчої діяльності виражається саме в художньо-образному освоєнні дійсності індивідом та дозволяє зрозуміти єдність пізнання, творчості й самовираження.

Художньо-творча діяльність характеризується такими ознаками: 1) вона є соціальним процесом, пов’язаним із духовно-практичною діяльністю юнаків і дівчат, спонукає їх до перетворення змісту діяльності, іiі гуманістичної спрямованості в емоційно-образних формах та забезпечує естетичне сприйняття дійсності; 2) забезпечує реалізацію культурологічної функції та виявляється у їх здатності творити культуру; 3) є соціально-психологічним явищем, що визначає емоційно-естетичну активність юнаків і дівчат; 4) розвиває комплексну здатність їх особистості до створення продуктів художньо-творчої діяльності (здатність до художньо-образного освоєння світу, в якому поєднуються об'єкти і суб'єкти, ставлення до них; здатність до створення художньої реальності: наочної, предметно-імітаційної, що викликають співпереживання й співчуття суб'єкта). Зазначимо, що художньо-творча діяльність є особливим видом діяльності студентської молоді в якій вона, самовиражаючись, саморозвиваючись, створює духовні цінності, які мають як об’єктивно-суспільну так і суб'єктивноособистісну значущість.

Художньо-творча діяльність студентів зумовлена специфічністю суб'єктів і умов, в яких вона відбувається та здійснюється в умовах освітнього процесу ЗВО, коли провідною є навчально-професійна діяльність. Так, процес навчання і процес художньо-творчої діяльності взаємопов'язані (навчання є підгрунтям для художньотворчої діяльності студентів, а художньо-творча діяльність є необхідною умовою ефективності процесу навчання та сприяє розвитку мотивації навчання, формує i розвиває емоційно-образну сферу, творчий потенціал студентів, особистісні новоутворення, гуманістичну культуру). Наголосимо, що художньо-творча діяльність, перш за все, є позааудиторною, яка не регламентується і не спрямовується, а має добровільний характер, здійснюється за власним вибором студента, планується із 
врахуванням його індивідуальних інтересів, схильностей і здібностей. Художньо-творча діяльність студентів може бути також як автономною (не пов'язаною із навчальним процесом і залежною від нього, так і відбуватися безпосередньо у процесі навчання, який визначає їі характер і зміст). Активна участь студентів у такій діяльності сприяє розвитку У них творчого потенціалу і гуманістичної культури.

Варто зазначити, що розвиток художньо-творчого потенціалу студентів багато в чому залежить від розкриття закладених у них можливостей здійснювати художньотворчу діяльність, яка тісно пов'язана зі знаннєвим та емоційним компонентами та загальною культурою особистості. Під впливом умов освітнього середовища формується потреба художньо-творчої інтерпретації отриманих знань. Відтак, розвиток художньотворчого потенціалу особистості студентів залежить від створення у вищому педагогічному закладі атмосфери творчості, відкритості та позитиву. Така атмосфера сприяє розвитку у студентів самостійності, активного пізнання нового, застосування отриманих знань на практиці. Основою для активізації художньо-творчого потенціалу майбутніх фахівців у процесі педагогічної підготовки є інтелект, рівень знань, уява та емоції.

Також у сучасних реаліях підготовки майбутніх фахівців-художників проблемне навчання є одним із дієвих методів прояву інтелектуальних творчих можливостей, творчої активності в самостійній діяльності, впевненості та вмінь творчо працювати. Через що, проблемне навчання характеризується залученням студентів до вирішення певних художньо-творчих проблем. Сюди ж відносимо і контекстне навчання, науководослідну роботу, ділові ігри. Як показує досвід, розвиток художньо-творчої активності студентів потребує застосування адекватних технологічних засобів. В якості такого засобу сучасними дослідниками пропонується імітаційна (моделююча) технологія, пов’язана 3 моделюванням в освітньому процесі ситуацій майбутньої професійної діяльності.

Педагогічна цінність імітаційної технології для розвитку художньо-творчої активності студентів у професійній мистецькій освіті полягає в наступному: скорочується розрив між професійною освітою та професійною діяльністю; сприяє баченню перспективи майбутньої професійно-мистецької діяльності, реалізує ідею прогностичності освіти. Ефективними є методи імітаційної технології, застосування 
яких у професійно-мистецькій освіті є найбільш доцільними для розвитку художньотворчої активності студентів. Це, наприклад, кейс-метод, мозковий штурм, дискусійний клуб, складання портфоліо творчих робіт, проходження практики в загальноосвітніх установах тощо.

Висновки. Підсумовуючи зазначимо, що в презентованій роботі ми здійснили аналіз стану розвитку художньо-творчої діяльності особистості в естетичному, психологічному, педагогічному контекстах. Художньо-творчу діяльність розглядаємо як ефективний засіб формування гуманістичної культури студентської молоді, важливу складову цілісної гуманістично орієнтованої моделі вищої освіти. Включення студентів у художньо-творчу діяльність розширює їх життєвий та художній світогляд, підвищує рівень їх емоційної сприйнятливості, розвиває здатність до оцінювання естетичних явищ, активізує художньо-креативні здібності, спричиняє збудження у них відчуття естетичної насолоди від художньої творчості.

\section{References}

1. Bakulina O. S., Ternopiljsjka V. I. Osoblyvosti zastosuvannja osvitnikh tekhnologhij u formuvanni mobiljnosti studentiv [Features application of educational technologies in formation of mobility students]. Pedagogical and psychological sciences: regularities and development trends: Collective monograph. Riga, Latvia: «Baltija Publishing», 2020. Pp. 370-385.

2. Kagan M. S. Filosofiya kul'tury [Philosophy of culture]. SPb. : Petropolis, 1996.

3. Ternopiljsjka V.I. Teoretychni zasady realizaciji cinnisnogho pidkhodu u vykhovanni osobystosti [Theoretical bases of realization of the value approach in education of the person]. Novi tekhnologhiji navchannja, 2016. Iss. 88. Pp. 118-121.

4. Ternopiljsjka V. I., Kolomijecj T. V., Piontkivsjka I. O. Dovidnyk z vykhovnoji roboty zi studentamy [Handbook of educational work with students]. Ternopilj : Navchaljna knygha. Boghdan, 2014.

5. Ternopiljsjka V.I. Modeljuvannja procesu formuvannja samoosvitnjoji kompetentnosti majbutnikh fakhivciv [Modeling the process formation of self-educational competence of future specialists]. Pedaghoghichna osvita: teorija i praktyka. Psykhologhija. Pedaghoghika, 2016. No. 25. Pp. 16-22.

6. Bakhov I., Brovko K., Ternopilska V., Chernukha N., Zagorodnya A. Research of motives for formation of corporate culture of students in the context of the paradigm of cognitive psychology. Journal of Advanced Pharmacy Education and Research, 2020. No. 10(2). Pp. 195-202.

7. Brovko K.,, Ternopilska V.,, N. M. Chernukha N., Zagorodnya Z., Bakhov I. Journal of Advanced Pharmacy Education \& Research. Apr-Jun 2020. Vol 10 . Issue 2. Pp. 195-202. 
8. Kostenko D., Karam Ah., Honchar L., Ternopilska., Chernukha N. Cross-cultural competence of personality and adaptation to polycultural environment: approaches and techniques. Intellectual Archive. Toronto: Shiny Word.Corp. (Canada), 2019. Vol. 8 (October/December). No. 4. Pp. 338-357. https://doi.org/10.32370/IA_2019_12_25

9. Pet'ko L. V. Brainstorming and the formation of professionally oriented foreign language teaching environment in the conditions of university (for the specialties 023 «Fine Arts» and 022 «Design») // Economics, management, law : challenges and prospects: Collection of scientific articles. Psychology. Pedagogy and Education. Discovery Publishing House Pvt. Ltd., New Delhi, India. 2016. P. 214-217.

10. Pet'ko Lyudmila. Developing students' creativity in conditions of university // Research: tendencies and prospects: Collection of scientific articles. - Editorial Arane, S.A. de C.V., Mexico City, Mexico, 2017. P. 272-276.

11. Pet'ko L.V. Formation of professionally oriented foreign language teaching environment in the conditions of university for students of specialties 023 «Fine Arts» and 022 «Design» // Economics, management, law: realities and perspectives: Collection of scientific articles. Psychology. Pedagogy and Education. - Les Editions L'Originale, Paris, France. 2016. - P. 466-471.

12. Turchynova G, Pet'ko L., Novak T. The Rose "Ophelia" and Flower Symbolism in "Hamlet". Intellectual Archive. Toronto: Shiny Word.Corp. (Canada). 2021. Vol. 10. No. 1. (January/March). Pp. 68-93. https://doi.org/10.32370/IA_2021_03_10

\section{Translation of the Title, Abstract and References to the Author's Language}

\section{УДК 378.14}

Цянь Кай. Дослідження художньо-творчої діяльності як засобу формування гуманістичної культури студентів.

У статті розглядається художньо-творча діяльність як важливий засіб формування гуманістичної культури студентів. Зазначено, що художньо-творча діяльність студентів зумовлена специфічністю суб'єктів і умов, в яких вона відбувається. Наголошено на художньо-творчій діяльності як необхідній умові ефективності процесу навчання, яка сприяє розвитку у студентів мотивації до навчання, емоційно-образної сфери, творчого потенціалу, гуманістичної культури. особистість.

Ключові слова: художньо-творча діяльність, гуманістична культура, студент, Лiтература

1. Бакуліна О.С., Тернопільська В. I. Особливості застосування освітніх технологій у формуванні мобільності студентів / Pedagogical and psychological sciences: regularities and development trends: Collective monograph. Riga, Latvia: «Baltija Publishing», 2020. Pp. 370-385.

2. Каган М. С. Философия культуры. СПб. : Петрополис, 1996. 416 с.

3. Тернопільська В. І. Теоретичні засади реалізації ціннісного підходу у вихованні особистості. Нові технології навчання. 2016. Вип. 88. Ч. 2. С. 118-121. 
4. Тернопільська В. І., Коломієць Т. В., Піонтківська І. О. Довідник з виховної роботи зі студентами. Тернопіль : Навчальна книга. Богдан, 2014. 264 с.

5. Тернопільська В. I. Моделювання процесу формування самоосвітньої компетентності майбутніх фахівців. Педагогічна освіта: теорія і практика. Психологія. Педагогіка. 2016. № 25. С. 16-22.

6. Bakhov I., Brovko K., Ternopilska V., Chernukha N., Zagorodnya A. Research of motives for formation of corporate culture of students in the context of the paradigm of cognitive psychology. Journal of Advanced Pharmacy Education and Research. 2020. No. 10(2). P. 195-202.

7. Brovko K.,, Ternopilska V.,, N. M. Chernukha N., Zagorodnya Z., Bakhov I. Journal of Advanced Pharmacy Education \& Research. Apr-Jun 2020. Vol 10 . Issue 2. Pp. 195-202.

8. Kostenko D., Karam Ah., Honchar L., Ternopilska V., Chernukha N. Cross-cultural competence of personality and adaptation to polycultural environment: approaches and techniques. Intellectual Archive. Toronto: Shiny Word.Corp. (Canada). 2019. Vol. 8 (October/December). No. 4. Pp. 338-357. https://doi.org/10.32370/IA_2019_12_25

9. Pet'ko L.V. Brainstorming and the formation of professionally oriented foreign language teaching environment in the conditions of university (for the specialties 023 «Fine Arts» and 022 «Design») // Economics, management, law: challenges and prospects: Collection of scientific articles. Psychology. Pedagogy and Education. Discovery Publishing House Pvt. Ltd., New Delhi, India. 2016. P. 214-217

10. Pet'ko Lyudmila. Developing students' creativity in conditions of university // Research: tendencies and prospects: Collection of scientific articles. - Editorial Arane, S.A. de C.V., Mexico City, Mexico, 2017. P. 272-276.

11. Pet'ko L. V. Formation of professionally oriented foreign language teaching environment in the conditions of university for students of specialties 023 «Fine Arts» and 022 «Design» // Economics, management, law: realities and perspectives: Collection of scientific articles. Psychology. Pedagogy and Education. - Les Editions L'Originale, Paris, France. 2016. P. 466-471.

12. Turchynova G, Pet'ko L., Novak T. The Rose "Ophelia" and Flower Symbolism in "Hamlet". Intellectual Archive. Toronto: Shiny Word.Corp. (Canada). 2021. Vol. 10. No. 1. (January/March). Pp. 68-93. https://doi.org/10.32370/IA_2021_03_10 